\title{
Correction to: Creating person-al space for unspoken voices during diagnostic medical imaging examinations: a qualitative study
}

\author{
Chandra Rekha Makanjee ${ }^{1 *}$, Anne-Marie Bergh ${ }^{2}$, Deon Xu ${ }^{1}$ and Drishti Sarswat ${ }^{1}$
}

\section{Correction to: BMC Health Serv Res 21, 954 (2021) https://doi.org/10.1186/s12913-021-06958-4}

Following publication of the original article [1], the authors identified an error in the References section and two errors in the citations due to a typesetting error.

The reference 24 and 25 should be exchanged.

The correct reference 24 and 25 should be:

24. Entwistle VA, Watt IS. Treating patients as persons: a capabilities approach to support delivery of person-centered care. Am J Bioeth. 2013;13(8):29-39. https://doi.org/10.1080/15265161.2013.802060.

25. Gilmore KJ, Pennucci F, De Rosis S, Passino C. Value in healthcare and the role of the patient voice. Healthc Pap. 2019;18(4):28-35. https://doi.org/10.12927/ hcpap.2019.26031.

In the main text of the article, two citations should be corrected:

1. The citation at the end of the following sentence should be changed from [25] to [24].

The unconventional hyphenation of 'person-al' is an attempt to keep the focus on the person, based on their 'best interests' and 'quality of life' (p. 56) [23] and to emphasise the human capabilities of patients as persons, which, according to Entwistle and Watt, include 'personal capabilities' (p. 34) [24].
2. The citation at the end of the following sentence should be changed from [24, 25] to [25].

This serves as a reminder of the importance of focusing on the whole person, not only biomedical markers and technical procedures [25].

The original article [1] has been corrected.

\section{Author details}

${ }^{1}$ Department of Medical Radiation Science, University of Canberra, University Drive, Bruce, ACT 2617, Australia. ${ }^{2}$ Research Centre for Maternal, Fetal, Newborn and Child Health Care Strategies, University of Pretoria, Private Bag X323, Gezina 0083, South Africa.

Published online: 27 September 2021

\section{Reference}

1. Makanjee, et al. BMC Health Serv Res. 2021;21:954.

The original article can be found online at https://doi.org/10.1186/s12913021-06958-4.

* Correspondence: chandra.makanjee@canberra.edu.au

'Department of Medical Radiation Science, University of Canberra, University Drive, Bruce, ACT 2617, Australia

Full list of author information is available at the end of the article

C C The Author(s). 2021 Open Access This article is licensed under a Creative Commons Attribution 4.0 International License, which permits use, sharing, adaptation, distribution and reproduction in any medium or format, as long as you give appropriate credit to the original author(s) and the source, provide a link to the Creative Commons licence, and indicate if changes were made. The images or other third party material in this article are included in the article's Creative Commons licence, unless indicated otherwise in a credit line to the material. If material is not included in the article's Creative Commons licence and your intended use is not permitted by statutory regulation or exceeds the permitted use, you will need to obtain permission directly from the copyright holder. To view a copy of this licence, visit http://creativecommons.org/licenses/by/4.0/ The Creative Commons Public Domain Dedication waiver (http://creativecommons.org/publicdomain/zero/1.0/) applies to the data made available in this article, unless otherwise stated in a credit line to the data. 